\title{
The Influence of Online Learning on Learning Interest and Motivation and Their Impact on Student Achievement at Educational Technology Study Program - Ibn Khaldun University Bogor
}

\author{
Mohammad Givi Efgivia*,1, Al-Bahra², Abdul Karim Halim³ ${ }^{3}$ R Andi Ahmad Gunadi ${ }^{4}$ \\ ${ }^{1}$ Postgraduate Educational Technology, University of Ibn Khaldun, Bogor, Indonesia \\ ${ }^{2}$ Master of Informatics Engineering Study Program, Raharja University, Tangerang Indonesia \\ ${ }^{3}$ Faculty of Teacher Training and Education, Ibn Khaldun University, Bogor Indonesia \\ ${ }^{4}$ Master of Educational Technology University of Muhammadiyah Jakarta
}

\begin{tabular}{l} 
A R T I C L E I N F O \\
\hline Article history: \\
Received: 01 August, 2021 \\
Accepted: 26 October, 2021 \\
Online: 30 November, 2021 \\
\hline Keywords: \\
Online Learning \\
Interest \\
Motivation \\
Student Achievement \\
\end{tabular}

\begin{abstract}
A B S T R A C T
The aim of this research was to prove the effect of online learning on interest and motivation to learn and its effect on student achievement in the Educational Technology Study Program - Ibnu Khaldun University, Bogor. This research method uses descriptive analysis and verification with a quantitative approach. The source of this research uses primary data. Collecting data using a questionnaire. The sample of this study was 40 students at the Education Technology Study Program IK University Bogor by performing both descriptive and path analysis for the random sampling technique.of this study indicate that online learning has a positive and significant effect on interest and motivation to learn. It is known that the total effect of online learning on students' interest in learning is $79.03 \%$, while the total effect on student learning motivation is $79.74 \%$. Interest in learning has Both interest in learning and learning motivation have contributed on student achievement which are measured by $29.6 \%$ and $51.07 \%$ respectively, with a total effect of $29.61 \%$. While learning motivation has a positive and significant effect on student achievement, with a total effect of $51.07 \%$.
\end{abstract}

\section{Introduction}

Coronavirus is an infectious disease, which spreads very quickly in Indonesia. Corona Virus 19 is a new disease that has been transmitted from Wuhan, China, in December 2019. This disease spreads in animals, however the virus can also be transmitted to humans [1]. Indonesia's Ministry of Education and Culture has instructed, that one way to implement the physical distancing program is to apply online learning to to suppress the sudden rise of COVID disease. Both students and education practitioners are asked to switch the face-to-face learning process to online [2]

In light of the ongoing covid health crisis, educators and students are in a state of uncertainty. In the conditions of uncertainty online learning, of course lots of questions arise regarding lots of question regarding to the deliverable and measurable impacts for both students and education practitioners. One of the fundamental questions for us in this research is student motivation in a new virtual platform that applies to all stakeholders. Understanding the variety that will impact student perceptions can also help administrators to make informed decisions about coursework and organizational design as well as hold professional development workshops for instructors.

*Corresponding Author: Mohammad Givi Efgivia, Email: mgivi@uikabogor.ac.id
This online learning policy applies to all educational institutions. This is done by changing the studying process which initially was in a personal approach to a remote online study. This significant adjustment has become a debate about quality. Several research in the past mentioned the significant cost of the online learning practice. Although other studies stated that it is disadvantageous, online learning is found to have many positive impacts which are shown by the interaction within the learning process and the flexibility of time and location, while other studies stated that it was a loss. Moreover, this is seen as an opportunity to adapt to an online learning experience [3]

In addition, high interactions also occur in In addition, high interaction also occurs in the digital space between educators and participants, and among participants which gives rise to the ability to share information and bread experiences [4]. The online learning process uses computer technology, this increases the interest of both educators and participants which also implies to the increase of computer literacy competence.

The digital study focuses on learning materials and deliverables. First, the learning materials affect student learning outcomes. This should involve distance learning This should involve distance learning according to the information technology by the cloud service with various medium of 
deliverables such as audio and visuals. Content capacity can be adjusted to the needs of students in bringing out their competence to understand the learning material and be ready to move on to new topics [5]. Second, instruction is done online where students can explain their assignments directly. Similarly, the deliverable is aligned to the needs of pedagogy, both hardware equipment and the communication rules will be aligned to the policy of the education provider [6] .

Instructions are given by teachers online as well as video conferencing using popular video conference applications and other messaging services. These platforms must be accessible from any time and anywhere..

Several studies on student learning motivation have been carried out, including by examining the influence of learning methods and learning motivation, student learning motivation on the learning process, the influence of the internet on student learning outcomes, factors that influence student learning motivation, the contribution of learning media in increasing student learning motivation., information technology-based learning media and much more. However, research on the effect of online learning on student learning motivation is rarely done [7] .

Learning motivation is an individual learner's opinion about the desire, then the learner will present different knowledge acquisition needs because of different opinions. Learning motivation is a belief that is embedded in the heart in directing individual learning goals, encouraging learning behavior to make continuous efforts, strengthening the history of cognition, and strengthening and improving learning outcomes [8] .

Leaning motivation is an individual learner's opinion about the desire, then the learner will offer a various processes of extracting, structuring, and organizing knowledge from one source due to a different personal need. A drive to learn is widely known coming from the heart in directing individual learning goals, encouraging learning behavior to make continuous efforts to learn, this is a student's choice of certain learning activities and efforts in these activities. Thus, this study defines learning motivation as guiding students to continue learning and efforts at learning goals set by the teacher in the learning process [9].

For online-learning environments [10] proves that students' positive emotions in various online learning activities are higher than negative emotions, especially during synchronous activities with teachers and with peers. They also proved that positive emotions experienced during exam preparation are closely related to student motivation which supports the learning process and student learning outcomes.

The emotion of student achievement is related to the domain to a large extent. However achievement emotions were analyzed in different content domains (such as school subjects, mathematics) [11], [12], research in teacher education broadly did not emerge. For example, there have been several studies on pre-service primary school teacher-specific math anxiety and student emotions in teaching internships [13] .

In this study, the authors discuss the internal psychological factors, namely interest and motivation. Interest is a powerful motivation that energizes learning, guides academic and career trajectories, and is critical to academic success. Interest is a psychological state of attention and influence on a particular object, and tends to last a long time to re-engage from time to time [14].

Recent research about brain functions demonstrates the value of interest and motivation in the development of academic skills, specifically for secondary students. FMRI have allowed researchers to study the activation of different areas of the brain during specific tasks. This research suggests that students need to be interested and motivated to learn in order for true learning, or activation of necessary brain regions, to take place [15]. On the other hand, students under stress or faced with a perceived threat are known to show decreased interest and motivation. The human brain is wired for survival, and, when presented with a perceived threat, the brain will transform into a reflex survival response.

This research aims to show the implication of the online education activity on learning enthusiasm and motivation and its impact on student achievement at Ibn Khaldun University Bogor majoring in Educational Technology

\section{Method}

The method in this research is a descriptive and verification method with a quantitative approach, because of the variables that will be examined in relation to the purpose of providing a structured, reliable, and carefully the description of the facts and the relationship between the variables studied online learning on interest and learning motivation and its impact on student achievement at Educational Technology Study Program - Ibn Khaldun University Bogor.

The type of data in this study used primary data, the data processed and used in this study were sourced from questionnaires/questionnaires. The sample for the study was 40 students at School $\mathrm{X}$ using a simple random sampling technique. The verification analysis used in this study is path analysis. Path analysis has a close relationship with Multiple Regression.

\section{Result}

\subsection{Descriptive Analysis}

Based on the descriptive analysis carried out, the findings of the percentage score of each online learning variable, learning interest, learning motivation and student achievement are shown in Table 1.

Based on the descriptive analysis above, it shows that online learning, learning interest, learning motivation and student achievement are categorized as sufficient. The indicator which has the highest percentage score at online learning variable, about using of self-learning materials with a percentage of $68.5 \%$, but regarding the utilization of electronic technology services has the lowest percentage, which is $64.8 \%$ this is because there are still students who are constrained by internet signals, internet quotas or inadequate gadgets.

In the interest in learning variable, the indicator that has the highest percentage score is about having curiosity with a percentage of 68.5\%, but regarding perseverance and enthusiasm in learning has the lowest percentage, which is $66 \%$. While on the motivation variable, the indicator that has the highest percentage score regarding the motivation to learn and the hopes in the future with a percentage of $67.5 \%$, but there are still students who lack motivation or desire to succeed. 
Table 1: Descriptive Analysis

\begin{tabular}{|c|c|c|c|c|c|}
\hline No. & Indicator & $\begin{array}{c}\text { Actual } \\
\text { Score }\end{array}$ & $\begin{array}{l}\text { Ideal } \\
\text { Score }\end{array}$ & $\%$ & Information \\
\hline & Online Learning $(\mathrm{X})$ & & & & \\
\hline \multirow{5}{*}{1} & Utilization of electronic technology services & 259 & 400 & $64.8 \%$ & Enough \\
\hline & $\begin{array}{l}\text { Utilization of computer media, such as computer } \\
\text { networks or digital media. }\end{array}$ & 263 & 400 & $65.8 \%$ & Enough \\
\hline & $\begin{array}{l}\text { Using learning materials to be studied independently (self. } \\
\text { learning materials). }\end{array}$ & 274 & 400 & $68.5 \%$ & Good \\
\hline & $\begin{array}{l}\text { Take advantage of the learning schedule, curriculum, } \\
\text { learning progress results and matters relating to education } \\
\text { administration can be viewed at any time on the } \\
\text { computer. }\end{array}$ & 268 & 400 & $67.0 \%$ & Enough \\
\hline & Total Online Learning & 1064 & 1600 & $66.5 \%$ & Enough \\
\hline & Interest in Learning (Y1) & & & & \\
\hline \multirow{7}{*}{2} & Perseverance in learning. & 267 & 400 & $66.8 \%$ & Medium \\
\hline & Awareness in learning. & 270 & 400 & $67.5 \%$ & Medium \\
\hline & Enthusiasm. & 267 & 400 & $66.8 \%$ & Medium \\
\hline & Enjoy the lessons taught. & 276 & 400 & $69.0 \%$ & High \\
\hline & Have curiosity. & 277 & 400 & $69.3 \%$ & High \\
\hline & Total & 1357 & 2000 & $67.9 \%$ & Medium \\
\hline & Interest to learn & & & & \\
\hline \multirow{2}{*}{3} & Learning Motivation (Y2) & 264 & 400 & $66.0 \%$ & Medium \\
\hline & There is a desire and desire to succeed & 270 & 400 & $67.5 \%$ & Medium \\
\hline
\end{tabular}

In the Student Achievement variable, the parameter with the highest percentage score is in the Affective domain with a percentage of $67.5 \%$, but the psychomotor domain has a low percentage score of $64 \%$ this is due to the lack of student activity due to distance/online learning during the pandemic. This shows that the perceptions of students in Educational Technology Study Program regarding Online Learning, Learning Interest, Learning Motivation and Student Achievement are considered less than optimal.

The next analysis is verification analysis, The results of the analysis can determine the impact of online learning on interest and learning motivation and its implications for Student Achievement in Educational Technology Study Program A series of data analysis processes using path analysis include testing the normality assumption, analysis of path coefficients and coefficients of determination, analysis direct and indirect effects and hypothesis testing.

\subsection{Normality Assumption Test}

Based on the table of Kolmogorov Smirnov test results, it can be seen that the significance value of the unstandardized residual in the substructure model 1, 2 and 3 has a significance greater than 0.05 , thus it can be proved that the data is normally distributed.

Table 2: Kolmogorov Smirnov Test

\begin{tabular}{|ll|r|r|r|}
\hline \multicolumn{7}{|l|}{ One-Sample Kolmogorov-Smirnov Test } \\
\hline & & $\begin{array}{c}\text { Unstandardized } \\
\text { Residual }\end{array}$ & $\begin{array}{c}\text { Unstandardized } \\
\text { Residual }\end{array}$ & $\begin{array}{c}\text { Unstandardized } \\
\text { Residual }\end{array}$ \\
\hline $\mathrm{N}$ & & 35 & 35 & 35 \\
Normal Parameters ${ }^{\mathrm{a}, \mathrm{b}}$ & Mean & .0000000 & .0000000 & .0000000 \\
& Std. Deviation & 6.13382878 & 6.40788798 & 5.97092413 \\
Most Extreme Differences & Absolute & .141 & .126 & .081 \\
& Positive & .096 & .099 & .078 \\
& Negative & -.141 & -.126 & -.081 \\
Test Statistic & & .141 & .126 & .081 \\
Asymp. Sig. (2-tailed) & & $.078^{\mathrm{c}}$ & $.176^{\mathrm{c}}$ & $.200^{\mathrm{c} .0 .}$ \\
\hline
\end{tabular}

3.3. Path Coefficient Analysis and Coefficient of

Determination

Sub Structure 1: Online Learning on Learning Interests

Path coefficient analysis will analyze the causal relationship between online learning and interest in learning.
Start from results of the questionnaires which have been distributed assisted with SPSS, the following results are obtained:

Table 3: Testing the Coefficient of Sub-Structural Paths 1

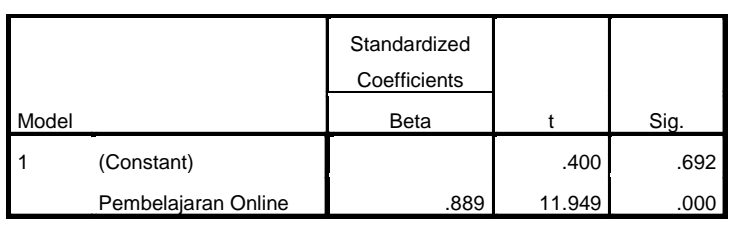

The structural model based on the standardized coefficients of Online Learning on Learning Interest is as follows:

$$
\mathrm{Y}_{1}=0.889(\mathrm{X})+\varepsilon_{1}
$$

The magnitude of the residual coefficient $(\varepsilon 1)$ and the magnitude of the effect can be known through the calculation results as follows:

Table 4: Coefficient of Determination of Substructure 2

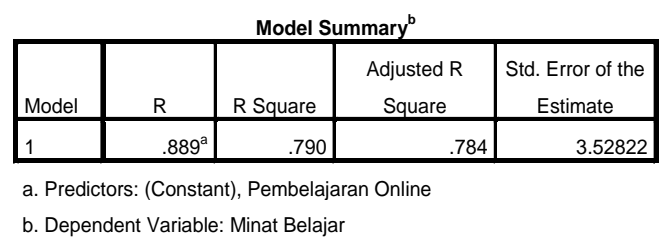

Based on the table above, it can be seen that the influence of Online Learning on Interest in Learning has a coefficient of determination of 0.790 . These results indicate that the online learning variable has an influence of $79 \%$ on learning interest, while the remaining $21 \%$ is influenced by other variables outside the known model.

\section{Sub Structure 2: Online Learning on Learning Motivation}

Path coefficient analysis would like to analyze the causal connection between online learning and learning motivation. After Seeing the results of the questionnaires which have distributed assisted with SPSS, the following results are obtained: 
Table 5: Testing the Path Coefficient of Sub Structure 2

\begin{tabular}{|ll|r|r|r|}
\hline \multirow{2}{*}{ Model } & \multicolumn{1}{|c|}{$\begin{array}{c}\text { Standardized } \\
\text { Coefficients }\end{array}$} & & \\
\cline { 2 - 3 } & \multicolumn{1}{|c|}{ Beta } & \multicolumn{1}{c|}{ Sig. } \\
\hline 1 & (Constant) & 1.058 & .297 \\
& Pembelajaran Online & .893 & 12.202 & .000 \\
\hline
\end{tabular}

The structural model based on the standardized coefficients of Online Learning on Learning Motivation is as follows:

$$
\mathrm{Y}_{2}=0.893(\mathrm{X})+\varepsilon_{2}
$$

The magnitude of the residual coefficient $\left(\varepsilon_{2}\right)$ and the magnitude of the effect can be known through the calculation results as follows

Table 6: Coefficient of Determination of Substructure 2

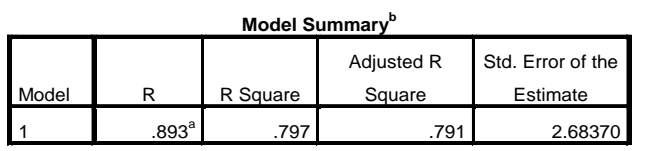

a. Predictors: (Constant), Pembelajaran Online

b. Dependent Variable: Motivasi Belajar

From the table above, seems like the influence of Online Learning on Learning Motivation has a coefficient of determination of 0.797 . These results have proved that the online learning variable has an effect of $79.7 \%$ on learning motivation, while the remaining $20.3 \%$ is influenced by other variables outside the known model.

Sub Structure 3: Interest and Learning Motivation on Student Achievement

Path coefficient analysis would mind analyzing the causal connection between Interest and Learning Motivation on Student Achievement. After seeing the results of the questionnaires which have distributed assisted with SPSS, the following results are obtained:

Table 7: Testing the Path Coefficient of Sub Structure 3

\begin{tabular}{|ll|r|r|r|}
\hline \multicolumn{2}{|c|}{} & $\begin{array}{c}\text { Standardized } \\
\text { Coefficients }\end{array}$ & & \\
\cline { 3 - 3 } Model & Beta & \multicolumn{1}{c|}{$\mathrm{t}$} & \multicolumn{1}{c|}{ Sig. } \\
\hline \multirow{2}{*}{1} & (Constant) & & .905 & .371 \\
& Minat Belajar & .344 & 2.118 & .041 \\
& Motivasi Belajar & .577 & 3.550 & .001 \\
\hline
\end{tabular}

The structural model based on standardized coefficients of Interest and Learning Motivation on Student Achievement is as follows:

$$
\mathrm{Z}=0,344\left(\mathrm{Y}_{1}\right)+0.577\left(\mathrm{Y}_{2}\right)+\varepsilon_{3}
$$

The magnitude of the residual coefficient $\left(\varepsilon_{3}\right)$ and the magnitude of the effect can be known through the calculation results as follows:

From table 8, it can be proved that the influence of Interest and Learning Motivation on Student Achievement has a coefficient of determination of 0.808 . These results indicate that the variables of Interest and Learning Motivation have an influence of $80.8 \%$ on student achievement, while the remaining $19.2 \%$ is influenced by other variables outside the known model.

Table 8. Coefficient of Determination of Substructure 2

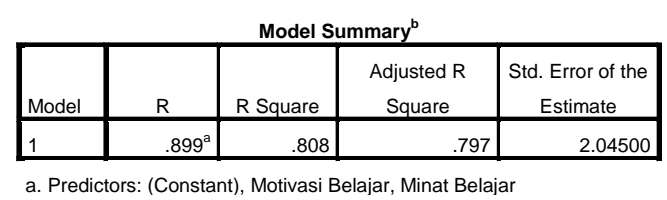

a. Predictors: (Constant), Motivasi Belajar, Minat Belajar

b. Dependent Variable: Prestasi Belajar

\subsection{Direct and Indirect Effect}

Based on the three equations above, the path of each variable is used to find the magnitude of the direct and indirect influence on each independent variable on the dependent variable, it could be seeing in below:

From table 9, we find that the online learning variable has a direct consequence on influencing learning motivation of $79.74 \%$, which is greater than its direct effect on learning interest, which is $79.03 \%$. Interest in learning has a direct effect of $11.83 \%$ smaller than the indirect effect of $17.78 \%$ on student achievement. Meanwhile, learning motivation has a direct effect of $33.39 \%$ greater than the indirect effect of $17.78 \%$ on student achievement. Therefore, it shows that in influencing student achievement, learning motivation has a higher influence than learning interest. Finally, we are able to say that if online learning is carried out properly supported by high interest and motivation in students, it will have an effect on high student achievement.

\section{Discussion}

\subsection{The Effect of Online Learning on Interest in Learning}

The Impact of online learning on interest in learning give the results of testing the first hypothesis, namely online learning on Interest in Learning, obtained a significant value $(0.000)<$ 0.05 so that $\mathrm{H}_{0}$ is denied, so we are able to say that online learning has a positive and important effect on Interest in Learning, with a positive direction indicating that it will be better learning done online, When students' interest in learning is getting higher, and conversely the worse the learning done online it is going to have an impact on the low interest in learning.

Research that has been carried out is in accordance with previous research which states that Interest plays a very important role in learning. Interest will lead to motivation to learn and improve learning outcomes. The strategy used by teachers in increasing students' interest in learning is to provide students with an understanding of the importance of learning, make learning materials simple, clear, and interesting, use interesting media, then carry out regular and continuous learning[1].

Table 9: Direct and Indirect Effect

\begin{tabular}{|c|c|c|c|c|}
\hline Variable & Direct Effect & Indirect Effect & $\begin{array}{c}\text { Total } \\
\text { Effect }\end{array}$ & $\begin{array}{c}\text { R- } \\
\text { Squared }\end{array}$ \\
\cline { 1 - 4 } $\mathrm{X} \rightarrow \mathrm{Y} 1$ & $(0.889)^{2}=79,03 \%$ & - & $79,03 \%$ & $79,03 \%$ \\
\hline $\mathrm{X} \rightarrow \mathrm{Y} 2$ & $(0.893)^{2} \times 100 \%=79,74 \%$ & - & $79,74 \%$ & $79,74 \%$ \\
\hline $\mathrm{Y} 1 \rightarrow \mathrm{Z}$ & $(0.344)^{2} \times 100 \%=11,83 \%$ & $0.344 \times 0.869 \times 0.577 \times 100 \%=17,78 \%$ & $29,61 \%$ & \multirow{2}{*}{$80,8 \%$} \\
\hline $\mathrm{Y} 2 \rightarrow \mathrm{Z}$ & $(0.577)^{2} \times 100 \%=33,29 \%$ & $0.577 \times 0.952 \times 0.344 \times 100 \%=17,78 \%$ & $51,07 \%$ & \\
\hline
\end{tabular}


It was found that there were differences in learning interest between male and female students where girls had a higher interest in learning than boys[16] .

\subsection{The Effect of Online Learning on Learning Motivation}

The results of testing the second hypothesis, namely Online Learning on Learning Motivation, obtained a significant value. $(0.000)<0.05$ so $\mathrm{H}_{0}$ is denied, it can be say that online learning has a positive and important effect on Learning Motivation, with a positive direction indicating that it will be better online learning, the higher student's motivation, and vice versa. Bad learning is done online, it is going to have an impact on the low learning motivation.

The findings of this study are reinforced in 2019. The use of specific learning strategies did not strongly relate to student performance in their course. Given the increasing popularity of online courses and programs, more attention should be paid to the way students approach and experience these courses, how student characteristics (such as different types of motivation) and activities (the way they learn and master the material) are closely related to their success [17].

The results of this study are not in accordance with the research conducted in 2017. The study proved that participants' extrinsic and intrinsic motivation were lower in online education when compared to face-to-face education and the researchers gave the reason students were less motivated in online courses was the lack of interaction with peers and teachers. Students stated that the higher level of motivation was due to the satisfying role of the teacher and adequate communication with the teacher [18]. Yantrapracorn et al. (2018) also stated that the negative impact of online learning courses in Thailand was discouraging teacher feedback [19].

The results of this study are not in accordance with the research conducted in 2021. Students' views are mostly negative in terms of online education based on the results of semi-structured interviews and students' creative writing assignments. The participants expressed various reasons for their lack of motivation in the online learning process including being dissatisfied with course content and materials, lack of discipline in attending courses, lack of communication with teachers and other students, in addition they stated that there was a lack of private space to take courses [20].

Motivation has proven to be an important, though not the most essential, element in supporting academic success. As many and as good as the tools and methods given to students to learn, there will be no progress in them, if they are not motivated to apply them [21].

\subsection{The Influence of Learning Interest on Student Achievement}

The results of testing the third hypothesis, namely Learning Interest on Student Achievement, obtained a significant value $(0.000)<0.05$ so that $\mathrm{H}_{0}$ is denied, can be say that Learning Interest has a positive and significant effect on Student Achievement, with a positive direction indicating that the higher students' interest in learning it will have an impact on high student achievement, and conversely the lower student interest in learning are going to have an impact on low student achievement.

The result of research in 2017 is a close relationship between student achievement and the interest of learning and student learning motivation, high learning achievement is resulted from the interest and motivation to learn that is owned by a student [22]. There is a mutual influence on learning motivation, learning interest, family environment and learning models together on student achievement in the Department of Economic Education of UIN Suska Riau [23].

This finding is in accordance with the research conducted in 2019. There is a significant effect of interest in learning and perceptions of teacher competency on social studies learning achievement. Thus, the interest in learning and teachers' pedagogic competency plays a very important role to determine and improve the learning achievement of Social Sciences [24].

\subsection{The Effect of Learning Motivation on Student Achievement}

The results of testing the fourth hypothesis, namely Learning Motivation on Student Achievement, obtained a significant value $(0.000)<0.05$ so that $\mathrm{H}_{0}$ is denied, wa could say that Learning Motivation has a positive and significant effect on Student Achievement, with a positive direction indicating that the higher students' motivation to learn it will have an impact on high student achievement, and conversely the lower student motivation to learn will have an impact on low student achievement.

The findings are in line with the study conducted in 2017. Motivation has a slightly positive effect on student achievement. The moderator variables, year of publication, type of publication, country, culture of research place, school subjects and sample groups will act as moderators in terms of the influence of motivation on student achievement [25].

The findings are accordance with 2020 study. Learning motivation has a positive and significant effect on the learning achievement of state high school students in the city of Padang. Stimulating learning and providing a more collaborative learning experience is generated through the integration of technology with face-to-face teaching. It is time for higher education to adapt to these changes to keep up with the increasing demands of both students and the workplace. The involvement, motivation, and interaction of students are the determining factors in order to achieve the success of the learning process. Students become more intrinsically motivated, when they can relate what they are learning to real life and personalize it [26].

\section{Conclusion}

Online learning has a positive and significant effect on learning interest. and Learning Motivation. Learning motivation also has a positive and significant effect on student achievement at the Educational Technology Study Program Ibn Khaldun University Bogor.

Lecturers are expected to be able to motivate students and create interesting learning, and always pay attention to students in the online learning process that takes place. In addition, lecturers also need to improve professional competence through training activities, seminars, and trainings so that they can use the media professionally in learning activities. Parents of students need to provide support for their children to learn and always pay attention to the condition of the child, accompanying the child in the learning process.

\section{References}

[1] A. Sariol, S. Perlman, "Lessons for COVID-19 immunity from other 
coronavirus infections,” Immunity, 2020.

[2] H. Harisman, M.S.Y. Lubis, M.R.S. Lubis, "The Implementation of Right-Fulfillment to the Education of Elementary School Students in the COVID-19 Pandemic Situation,” Randwick International of Social Science Journal, 2(4), 476-484, 2021. DOI: 10.47175/rissj.v2i4.328

[3] F. Firman, S. Rahayu, "Pembelajaran online di tengah pandemi covid19,” Indonesian Journal of Educational Science (IJES), 2(2), 81-89, 2020.

[4] R. Pakpahan, Y. Fitriani, "Analisa pemanfaatan teknologi informasi dalam pembelajaran jarak jauh di tengah pandemi virus corona covid-19," Journal of Information System, Applied, Management, Accounting and Research, 4(2), 30-36, 2020.

[5] D. Alabbasi, "Exploring graduate students' perspectives towards using gamification techniques in online learning," Turkish Online Journal of Distance Education, 18(3), 180-196, 2017.

[6] Y. Shi, "Handbook on Facilitating Flexible Learning During Educational Disruption: The Chinese Experience in Maintaining Undisrupted Learning in COVID-19 Outbreak,” Bulletin of the Technical Committee on Learning Technology (ISSN: 2306-0212), 20(2), 36-38, 2020.

[7] R.S.I. Kawet, "Pengaruh metode pembelajaran dan minat belajar mahasiswa terhadap hasil belajar manajemen konstruksi,” JTP-Jurnal Teknologi Pendidikan, 19(3), 224-239, 2017.

[8] K. Shabani, "Dynamic assessment of L2 learners' reading comprehension processes: A Vygotskian perspective,” Procedia-Social and Behavioral Sciences, 32, 321-328, 2012.

[9] L. Koff, R. Mullis, "Nutrition education and technology: can delivering messages via new media technology effectively modify nutrition behaviors of preschoolers and their families?," Journal of Nutrition Education and Behavior, 43(4), S40, 2011. DOI: 10.1016/j.jneb.2011.03.120

[10] F. D’Errico, M. Paciello, L. Cerniglia, "When emotions enhance students' engagement in e-learning processes," Journal of E-Learning and Knowledge Society, 12(4), 2016.

[11] K. Musnah "Zero Waste] dalam Mekanisme Bersih Pengelolaan Sampah Kota Tanpa TPA, 2015.

[12] M. Bieg, T. Goetz, F. Sticca, E. Brunner, E. Becker, V. Morger, K. Hubbard, "Teaching methods and their impact on students' emotions in mathematics: an experience-sampling approach,” ZDM, 49(3), 411-422, 2017. DOI: $10.1007 / \mathrm{s} 11858-017-0840-1$

[13] R. Yuan, I. Lee, "I need to be strong and competent': A narrative inquiry of a student-teacher's emotions and identities in teaching practicum," Teachers and Teaching, 22(7), 819-841, 2016. DOI: 10.1080/13540602.2016.1185819

[14] J.M. Harackiewicz, J.L. Smith, S.J. Priniski, "The Importance of Promoting Interest in Education. Policy Insights Behav,” Brain Sci, 3, 220-227, 2016.

[15] S. Sutarto, D.P. Sari, I. Fathurrochman, "Teacher strategies in online learning to increase students' interest in learning during COVID-19 pandemic,” Jurnal Konseling Dan Pendidikan, 8(3), 129-137, 2020. DOI: 10.47175/jkdp.v2i4.328

[16] S. Rodiah, W. Sopandi, "The Effect of Online Learning on Learning Interest and Digital Literacy of Students in terms of Gender (GenderBased Comparative Causal Study of Students' Learning Interest and Digital Literacy in Distance Learning Due to the Covid-19 Primary School Pande," in International Conference on Elementary Education, 233-237, 2021.

[17] E. Stark, "Examining the Role of Motivation and Learning Strategies in Student Success in Online versus Face-to-Face Courses.," Online Learning, 23(3), 234-251, 2019.

[18] C.-H. Lin, Y. Zhang, B. Zheng, "The roles of learning strategies and motivation in online language learning: A structural equation modeling analysis," Computers \& Education, 113, 75-85, 2017.

[19] P. Yantraprakorn, P. Darasawang, P. Wiriyakarun, "Self-efficacy and online language learning: causes of failure," Journal of Language Teaching and Research, 9(6), 1319-1329, 2018.

[20] M. Esra, Ç. Sevilen, "Factors influencing EFL students' motivation in online learning: A qualitative case study," Journal of Educational Technology and Online Learning, 4(1), 11-22, 2021.

[21] F. Koca, "Motivation to Learn and Teacher-Student Relationship.," Journal of International Education and Leadership, 6(2), n2, 2016.

[22] D. Hude, M. Si, I.F. Rohmah, "Analysis of Student Learning Interest and Student Learning Motivation in Enhancement Student Learning Achievement at School,” International Journal of Current Research, 9(10), 58981-58985, 2017.

[23] L. Lastri, S. Kartikowati, S. Sumarno, "Analysis of Factors that Influence Student Learning Achievement,” Journal of Educational Sciences, 4(3), 679-693, 2016. DOI: 10.1080/13542.2016.11819

[24] S.O. Özen, The effect of motivation on student achievement, Springer: 35-56, 2017.

[25] A. Susanto, S. Imawati, L. Qurrotaini, “The Effect of Learning Interest and Student's Perception of Teacher's Pedagogic Competency on
Learning Achievement of Social Sciences: Survey at Labschool Elementary School, Faculty of Education, University of Muhammadiyah Jakarta," in 6th International Conference on Community Development (ICCD 2019), Atlantis Press: 33-35, 2019.

[26] R. Rafiola, P. Setyosari, C. Radjah, M. Ramli, "The Effect of Learning Motivation, Self-Efficacy, and Blended Learning on Students' Achievement in The Industrial Revolution 4.0,” International Journal of Emerging Technologies in Learning (IJET), 15(8), 71-82, 2020. 